\title{
Construction of remains of small-scale mining activities as a possible innovative way how to prevent desertification
}

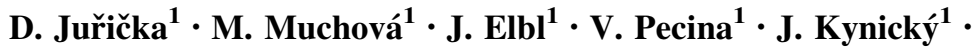 \\ M. Brtnický ${ }^{1} \cdot$ Z. Rosická ${ }^{1}$
}

Received: 3 June 2015/Revised: 12 January 2016/Accepted: 17 February 2016/Published online: 8 April 2016

(C) Islamic Azad University (IAU) 2016

\begin{abstract}
Initial mapping of secondary succession in places disturbed by mining of the Khan Khentii Strictly Protected Area in Mongolia shows a possible innovative direction taken by afforestation in order to prevent further expansion of the Gobi Desert in northern Mongolia. The study results from the knowledge of secondary succession of mined areas, which are classified as the remains and consequences of prospecting and mining work dated to the Soviet times. Ongoing succession on sites affected by mining is very slow. In quarry dumps and canavas, herb layer has not been recovered despite the fact that the prospecting and mining activities had finished more than 30 years ago. Herbs biodiversity is very poor in these areas. Conversely, representatives of the tree layer, especially Larix sibirica and Populus tremula, are found far from the continuous forest; they colonized sites located within the aridized steppe. We assume that the main factor of successful tree growth on the mining activities remains consists in the humidity condensation due to and caused by the specific shape of the canavas and dumps. Trees prosperity on these extreme habitats can be ensured particularly in the early stages of growth when the tree roots are unable to reach the groundwater table. Detail mapping of quantitative and qualitative parameters of trees shows that the dump is an ideal shape of self-watering condensation mound for forest growth and can prevent the desertification as well.
\end{abstract}

D. Juřička

djuricka@seznam.cz

1 Department of Geology and Pedology, Faculty of Forestry and Wood Technology, Mendel University in Brno, Brno, Czech Republic
Keywords Condensation - Larix sibirica · Mining · Goricho · Dzun Bayan

\section{Introduction}

Research activities were concentrated on two areas, and they differed in human activities load. The first locality Goricho belongs to the "buffer" zone between the Gobi Desert and mountain forest-steppe of the Khan Khentii Strictly Protected Area; it is the locality suffering from severe anthropogenic affects (forest grazing, intensive ledge steppes and illegal logging). Dzun Bayan locality, which does not suffer from human-based activities consequences, is found north of the Goricho locality within the area of mountain-steppe up to taiga ecosystem; those exclusively rare ecosystems protect the northern location, light and dark taiga from the Gobi Desert expansion. The Khentii mountain range has also been of historical importance as to mining the precious minerals from the numerous pegmatites present in this territory.

Highly unique quarries have recently been identified and studied in detail in pegmatites of the Gorkhi massif and Dzun Bayan massif in northern Mongolia. Quarry heaps and remains left after the prospecting activities (canavas, exploratory grooves) are longitudinally or transversely oriented elongated grooves in a slope, on the surface excavated for the purpose of detecting rocks of the interest (especially pegmatite). They are found within the arid steppe environment up to the mountain forest-steppes of northern Mongolia; those had particularly been colonized by Larix sibirica and Populus tremula. Woody plants apply this colonization method for the steppe habitat outside the continuous forest. The authors discuss the hypothesis based on the principle the water vapour condensates from the air 
humidity on canavas and dumps; this fact is allowed due to the extreme temperature changes by day and night, and canavas and dumps specific shape. Mapping the woody species composition and the extent of its prosperity resulting from the secondary succession within the studied sites show, which areas affected by mining in the north Mongolia natural conditions can work best as the initial stand for the woody species being forwarded towards the southerly locations of the Khentii Mountains. These findings might result in the construction of the ideal dump, which could be applied within the afforestation work not only in Mongolia but also in other arid areas.

In Mongolia, cold arid climate dominates (Dashkhuu et al. 2015). Rainfall is distributed mainly in July and August; the maximum total reaches $400 \mathrm{~mm}$ a year (Ykhanbaiet 2010). In Mongolia, weather conditions are extreme, and temperatures in winter can also fall at $-50{ }^{\circ} \mathrm{C}$ (Marin 2010). Maintaining and expanding forests depend on water, an essential element encouraging the desertification prevention; due to global climate changes, the problem of water deficiency is becoming more and more critical issue. Structure and distribution of vegetation is a diagnostics of water-supply ecosystem (Anenkhonov et al. 2015) and can determine the development trend of landscape and vegetation in the future ( $\mathrm{Li}$ and Yang 2014). Due to lower rainfall caused by global warming, it leads to dry out already arid regions (Hu et al. 2015). Lioubimtseva et al. (2005) presupposes increase in Central Asia by $1-2{ }^{\circ} \mathrm{C}$ during the years $2030-2050$. Mongolia landscape is also a subject to chronic aridization, in particular the decline in rainfall (Khishigjargal et al. 2014), which is reflected in the vegetation structure and can lead to a permanent change (Anenkhonov et al. 2015). These changes lead also currently to degradation of permafrost in Mongolia (Kynicky et al. 2009).

\section{The history and origin of mining activities in Khentii Mountains}

Dominated by desert, mountains and arid to semi-arid plains, Mongolia contains very little arable land. Some $30 \%$ of the population is nomadic or semi-nomadic, and almost no scientific data are available. The Mongolian economy has traditionally been based on herding and agriculture; however, the country's extensive mineral deposits began attracting both Mongolians and foreigners from Chingischan golden era.

Later, in the 1920s, the Gorkhi granitic massif (the Goricho Mountains being a part of this massif) and Dzun Bayan granitic massif were explored and for the first time described in the scientific literature by a Russian mineralogist Alexander Fersman who discovered the massif's miarolithic pegmatites, containing feldspar, quartz, mica, fluorite, topaz and beryl crystals. In the 1960s, Russian geologists began making regular expeditions to the area, and in the following decades, the pegmatites were mined for optical quartz and fluorite (Antipin et al. 1976; Kynický and Jaroš 2005).

However, as early as 200 years ago, the Chinese apparently prospected the $10-\mathrm{km}$-wide and $15-\mathrm{km}$-long Gorkhi massif and three times larger Dzun Bayan granitic massif, which are today ranked among the auspices of the Gorkhi-Terelj National Park and Khan Khentii Strictly Protected Area.

\section{Goricho and Dzun Bayan location and geological characteristics}

The Gorkhi granitic massif is one of the smallest, however, the best-known massifs in the Khentii synclinorium of northern Mongolia, Goricho Mountains; it is located approximately $35 \mathrm{~km}$ east of Ulaanbaatar with elevation of the highest hill about $2000 \mathrm{~m}$ above sea level: the elliptic egg-shaped massif is of $10 \times 15 \mathrm{~km}$ diameter. The massif contains 800 separate pegmatites, whose average thickness is of about one metre, the largest one up to $20 \mathrm{~m}$ (Antipin et al. 1976). Pegmatite bodies constitute lenses, pipes and veins. These LCT pegmatites are highly fractionated and consist of granitic zones and miaroles, with some exhibiting metasomatic replacement units. The pegmatites are mostly found close the coarse-grained contact zone between the massif and the surrounding sedimentary rocks. Those are typical miarolitic bodies containing one or two main miaroles and several smaller crystal bearing vugs: beryl, topaz and fluorite are the most abundant there (Kynický et al. 2005).

Dzun Bayan massif is the largest granitic massif of all "ulaanbaatar region massifs" in Khentii synclinorium. It is located on the west bank of the Tuul River about $45 \mathrm{~km}$ north-east of Gorkhi massif, and it is $25 \times 20 \mathrm{~km}$ in diameter (about $400 \mathrm{~km}^{2}$ in actual erosion level). Dumps left after small-scale mining activities are irregularly spread on the slopes of the massif's steppes (1600-1800 m above sea level). The massif intruded surrounded terigenic sediments in Mesozoic age. As for the structure, the massif belongs to Khentii synclinorium. Surrounding rock of the intruded massif belongs to Gorkhi formation located in the southern part of the Khentii sedimentary supergroup (Antipin et al. 1976). 
The massif and its hollow pegmatites carry important economic mineralization of $\mathrm{Sn}, \mathrm{W}, \mathrm{Ta}, \mathrm{Nb}$ and various optical mineral assemblages, in addition to the typical main pegmatite minerals such as quartz, orthoclase, albite and microcline. The main accessory and economic mineral assemblage is represented by cassiterite, wolframite, eshinite, niobite, titanite, garnet, apatite, zircon, allanite, fluorite, topaz and beryl; many other rare minerals are present as well (Antipin et al. 1976; Kynický and Jaroš 2005).

\section{Materials and methods}

The research was carried out between July-August, 2014 and June-July, 2015. Our research covered mapping and examining the remains of small-scale mining activities at Goricho and Dzun Bayan locations (Fig. 1) because of important landscape phenomena. The manuscript is aimed at explaining the principle of moisture regime of dumps and canavas from air humidity condensation, as the main factor how tree water supply is arranged during the first years of development before the roots are able reach the active permafrost layer where water is found (at Goricho in the depth of $9 \mathrm{~m}$ during dry periods-own observations). Having applied the dendrometric mapping results, we can determine the site where trees show the best values of the parameters measured.

Therefore, we would like to find the most suitable model of condensing mound working best in natural condition environment. Further, the grain size composition of dumps and canavas was also investigated so that a starting point for substrate characteristics improvement could be found and higher condensation efficiency reached.

\section{Field of research}

We examined the tree species diversity, tree qualitative and quantitative parameters as well as abundance of herbal species and the overall coverage (Mühlenberg et al. 2012). Using the Šimek method (Šimek 2014), qualitative parameters are presented in Table 1; quantitative parameters are given in Table 2. The tables comprise data on tree dimensions, physiological and biomechanic vitality, arbory value and dendrological potential research areas. In addition, there were calculated further parameters such as number of standing deadwood of $>10 \mathrm{~cm}$ in diameter, number of standing deadwood of $>50 \mathrm{~cm}$ diameter, number of fallen deadwood of $>10 \mathrm{~cm}$ diameter, and number of fallen deadwood of $>50 \mathrm{~cm}$ diameter.

Height of trees was measured using an altimeter Sylva CM-1015-2025 and rangefinder Nikon Laser Forestry. Coverage of herb and trees was found using an expert estimate. Botanical mapping was aimed to determine total coverage of herb layer and individual species within the locality.

Remains of mining activity were mapped even pedologically. Having used soil samples from the canavas and dumps, grain size analyses were performed using Kopecký method (fraction-sand $2-0.1 \mathrm{~mm}$, silt sand $0.1-0.05 \mathrm{~mm}$, silt $0.05-0.01 \mathrm{~mm}$, particles of size less than $0.01 \mathrm{~mm}$ ) (Zbíral 1996).

\section{Area selected}

The Khentii Mount territory comprised much higher number of canavas than dumps. The significant dumps portion was found within Goricho locality (canavas locality is marked using GPS points $107.376902 \mathrm{E}, 47.846582 \mathrm{~N}$; $107.390644 \mathrm{E}, 47.847546 \mathrm{~N} ; 107.401565 \mathrm{E}, 47.864535 \mathrm{~N}$ and $107.378401 \mathrm{E}, 47.863572 \mathrm{~N})$; on the slopes they were comparatively regularly positioned in rows next to each other (Fig. 2). At Goricho site, there are currently 123 canavas; 50 canavas were explored and documented. Canavas were selected so that between each of them all natural variables (position on the slope, elevation and exposition) could be found and evenly distributed. Observed canavas were at hillsides with slopes of $15-30^{\circ}$, elevation from 1600 to $1800 \mathrm{~m}$ above sea level and were exposed to the west, south, east and north and their combinations. There were no significant differences between the individual canavas in parameters of quality and quantity considering natural conditions.

Dumps were scattered within the landscape irregularly; their numbers were significantly lower than that of canavas; however, they were found in Goricho (the same as canavas locality), Dzun Bayan (within the massif, the locality is marked with the Dzun Bayan river valleyRight Bayan: it is limited with points 107.779513E, 48.077039N; 107.742965E, 48.223424N). Totally, only 15 dumps were seen, and 7 of them were documented. The situation was similar to the canavas case; all of the dumps were located in different natural conditions. 
Fig. 1 Map of area of interest (ArcGis 10.2., Esri,

DigitalGlobe, GeoEye,

Earthstar Geographics, CNES/ Airbus DS, USDA, USGS, AEX, Getmapping, Aerogrid, IGN, IGP, swisstopo and the GIS User Community)
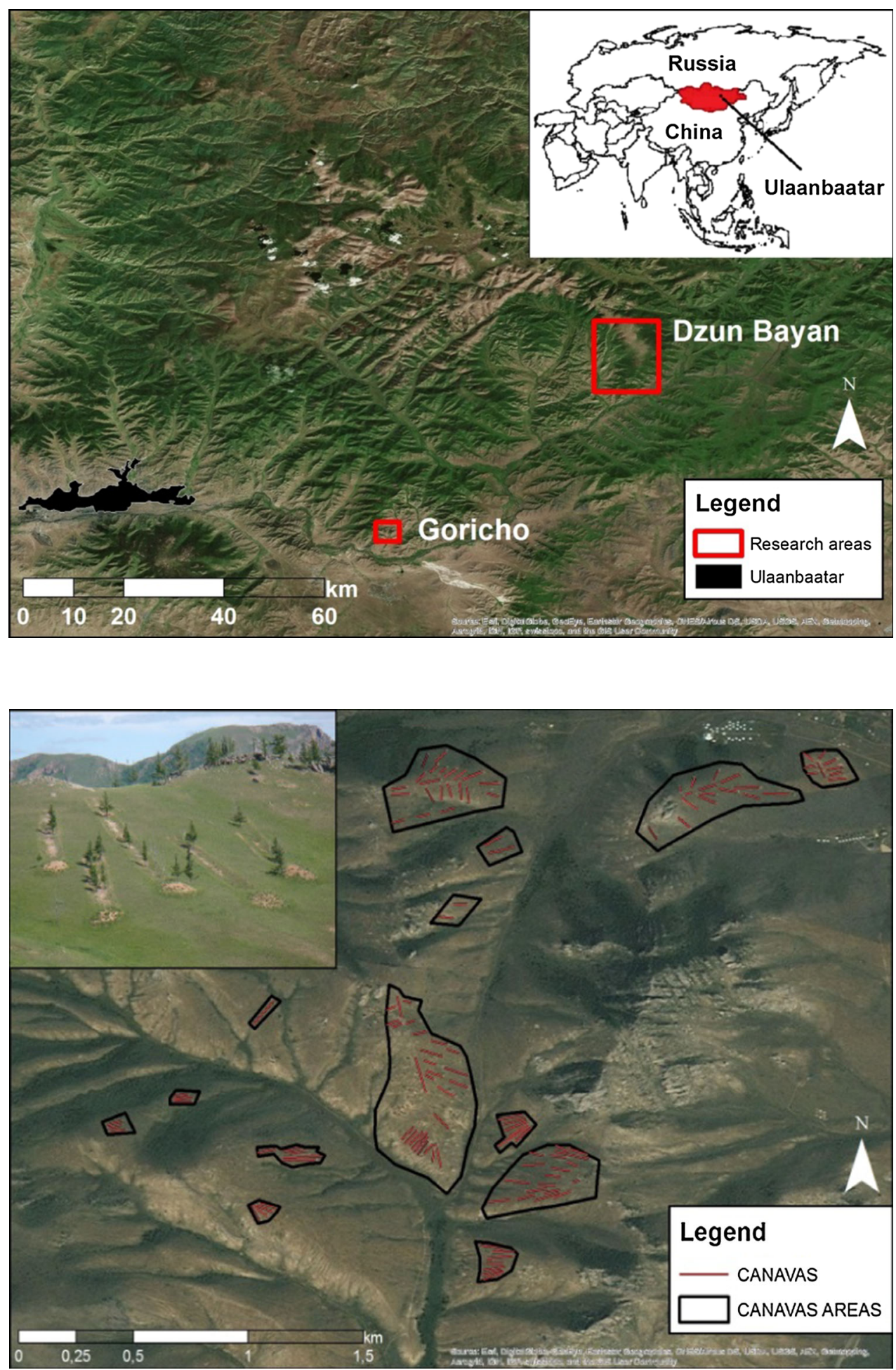

Fig. 2 Goricho

canavas (ArcGis 10.2., Esri, DigitalGlobe, GeoEye,

Earthstar Geographics, CNES/ Airbus DS, USDA, USGS,

AEX, Getmapping, Aerogrid, IGN, IGP, swisstopo, and the GIS User Community) between the individual dumps in parameters of quality and quantity considering natural conditions. Trees at dumps did very well regardless the natural condition variability. 
Fig. 3 Site view of the dump

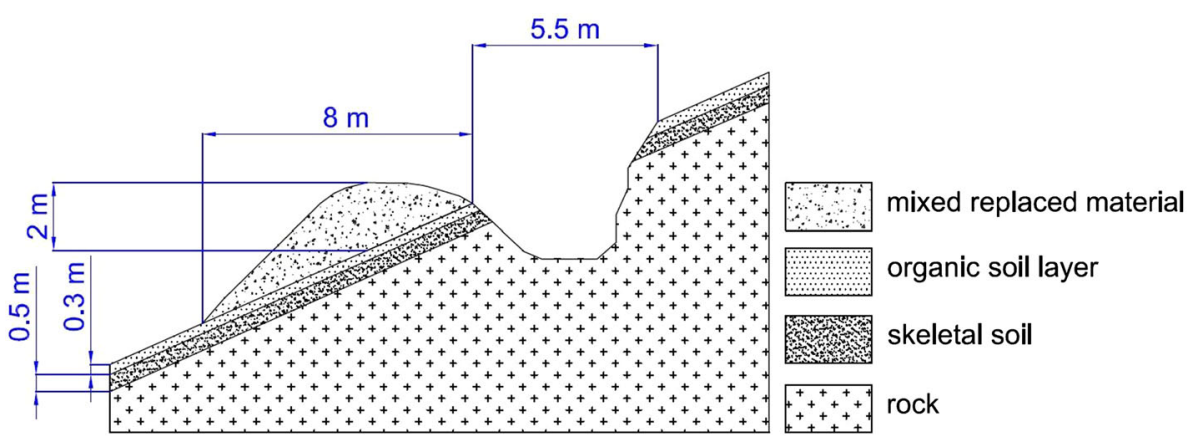

Fig. 4 Delineation of the dump

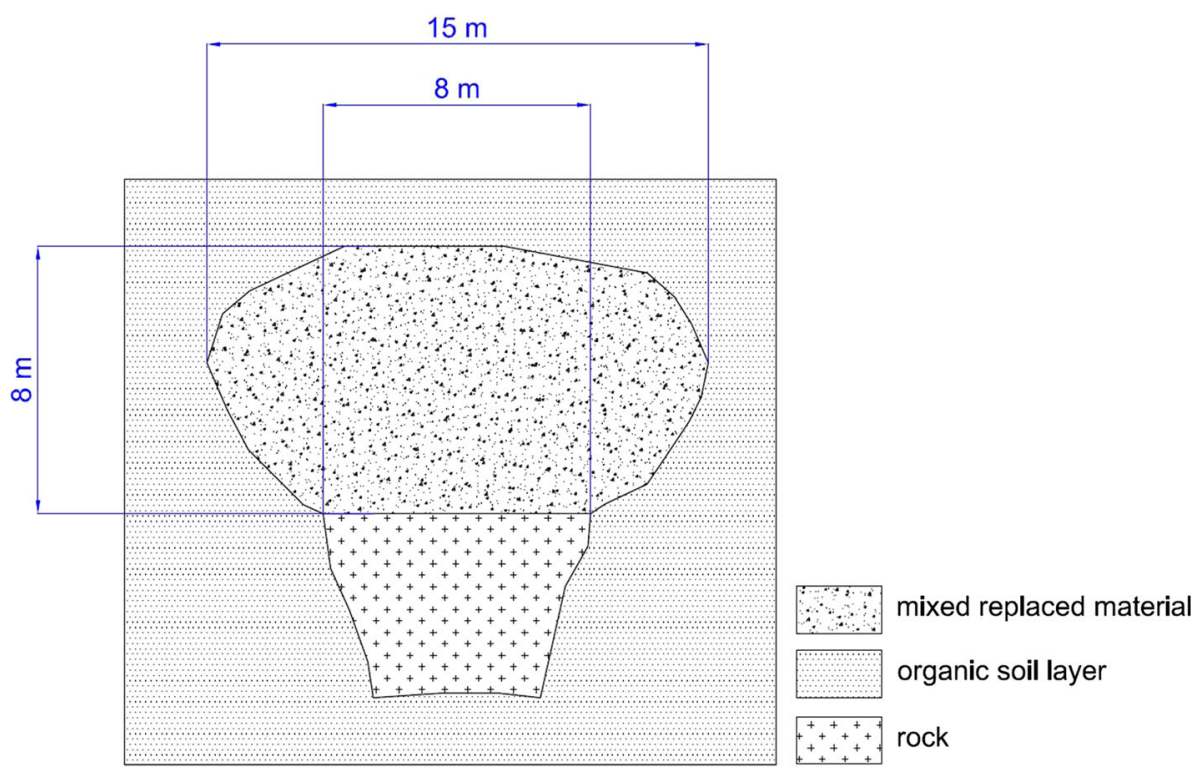

\section{Calculation of active condensation area}

The active condensation area (ACA) is characterized as the area where efficient condensation of atmospheric moisture occurs. The efficient condensation in terms of this paper is dealing with the condensation on entities, which are able to gather higher quantities of condensed water compared to the outside environment (i.e. dumps, and canavas versus the steppe). In terms of dumps, there is considered the entire surface area, i.e. the area being exposed to the solar radiation. This area was automatically derived from a 3D model (Fig. 5) simulating the surface heterogeneity of actual dumps using the function "area". The 3D model ACA results from the model dump characteristics: see Figs. 3 and 4 (mixed replaced material). 2D and 3D models of canavas and dumps were created using AutoCad2014 program (Fig. 5).

The canava ACA considers the left and right lateral mounds (they are identical for the calculation purpose) and the end mound (Figs. 6, 7-mixed replaced material,

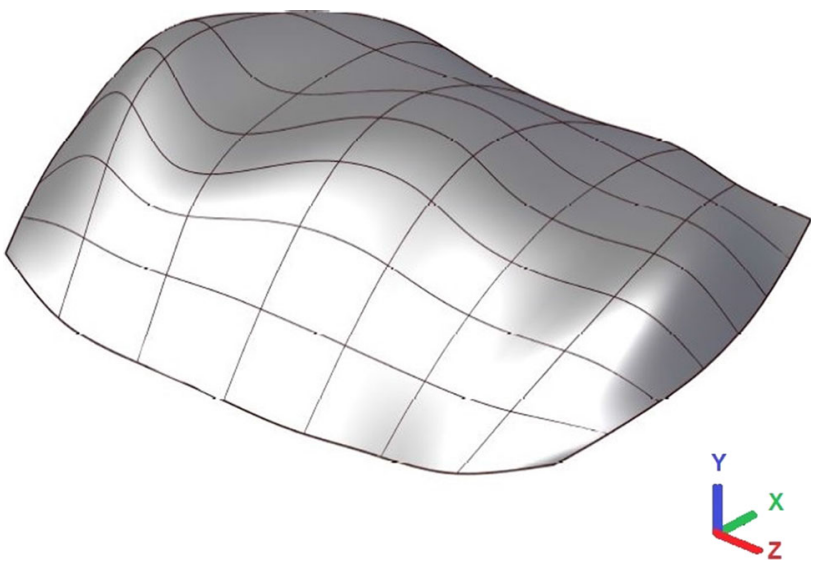

Fig. 5 Dump 3D model

Fig. 8-blue colour). In this case, those are areas offering sufficient cooling at night and morning periods required for efficient condensation of the atmospheric moisture. The canava ACA is calculated as the area 
Fig. 6 Canavas delineation

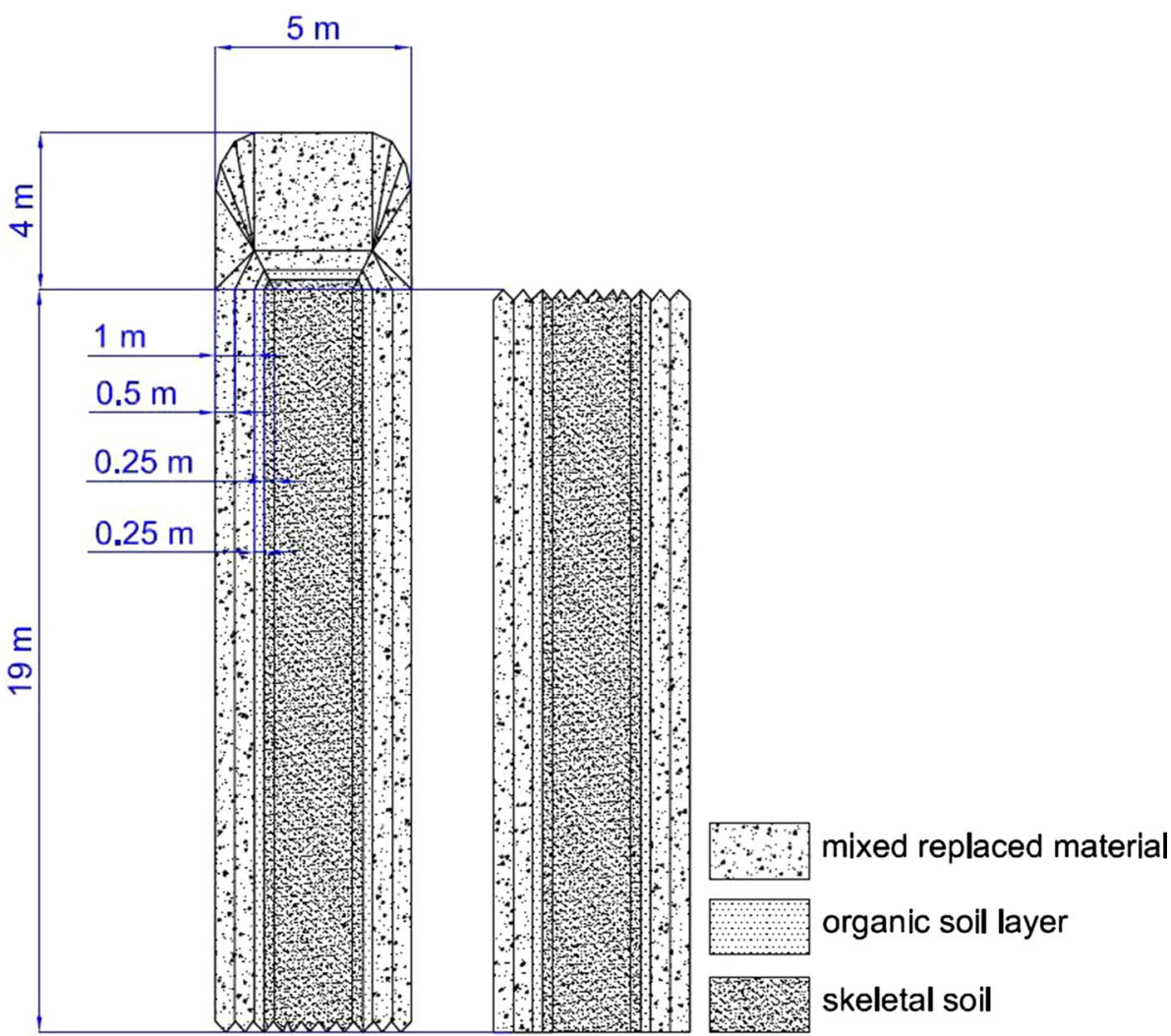

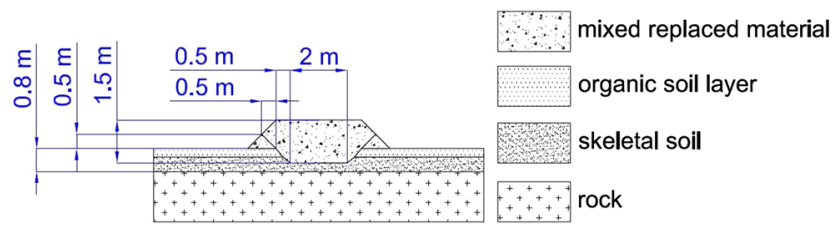

Fig. 7 Plan view of canavas

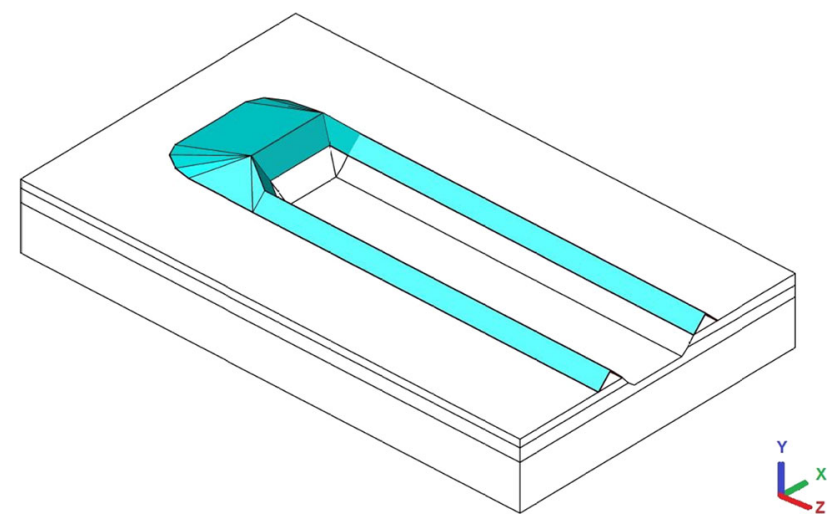

Fig. 8 Canava 3D model, active condensation area-blue colour

consisting of geometric shapes. In terms of calculation, the lateral canava mound is of an equal-armed triangle, whose arm is $0.7 \mathrm{~m}$ long.

\section{Results and Discussion}

The results demonstrate the shape and design of the mining activity remains. Furthermore, these sites are characterized dendrologically in terms of the quantitative and qualitative content. There are also remains of small mining operations described in terms of character and grit substrate from which they are formed. These data will be discussed, and the following facts serve to confirm or refuse hypotheses dealing with the role of moisture subsidies (air humidity condensation) for the tree growth on canavas and dumps and evaluate the most efficient shape.

\section{Characteristics and state of mining activity in question}

Small-scale mining activities are referred to as pits up to the depth of $10 \mathrm{~m}$ or recess to a slope, which are directly joined with the dump of loose waste material of especially psephitic fraction. Dumps are usually of irregular trapezoid or semicircle shape. Each side of dumps can even be more than $10 \mathrm{~m}$ long and more than $2 \mathrm{~m}$ high (Figs. 3, 4, 9, 10, 11, 12).

On average, canavas are 50-123 m long, $2 \mathrm{~m}$ wide and ended with a dump about $2 \times 5 \mathrm{~m}$ large. These grooves were formed using bulldozer which ploughed shallow soil 


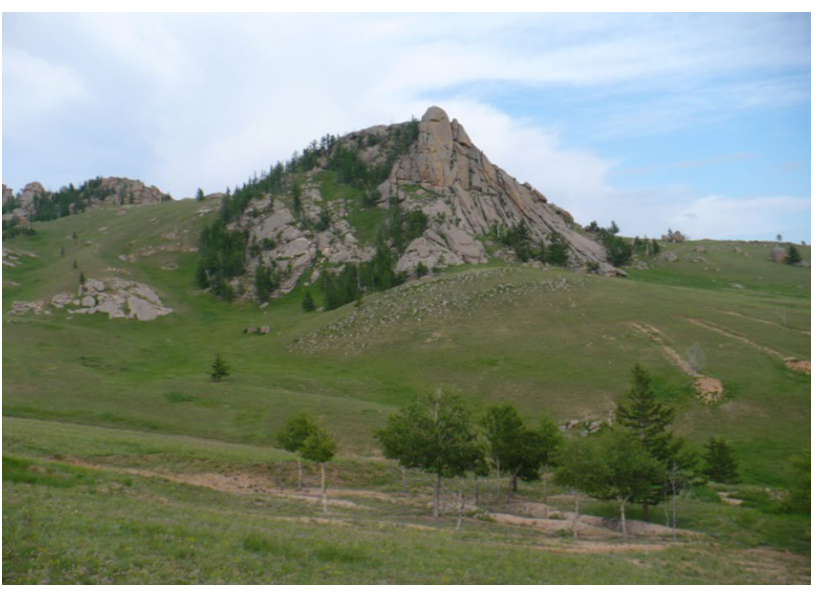

Fig. 9 Dump Goricho-Populus tremula vegetation

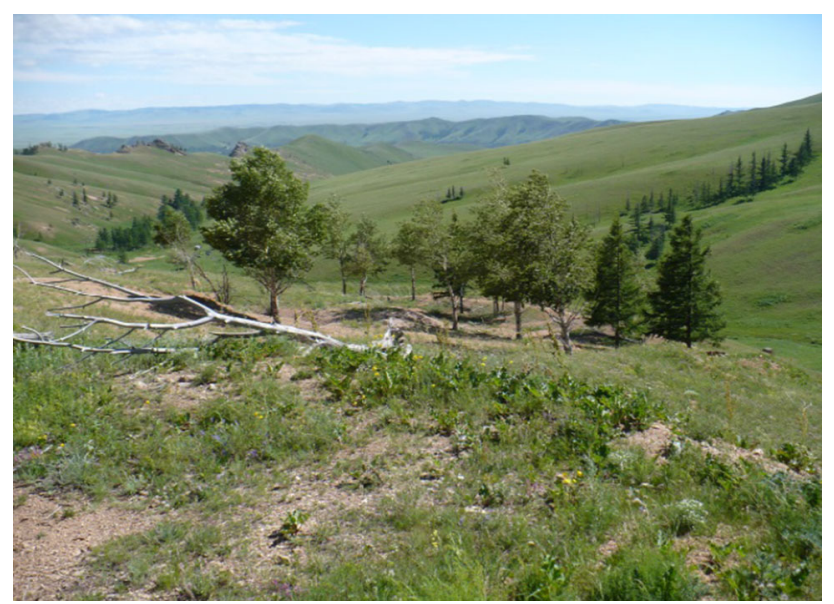

Fig. 10 Dump Goricho-Populus tremula vegetation

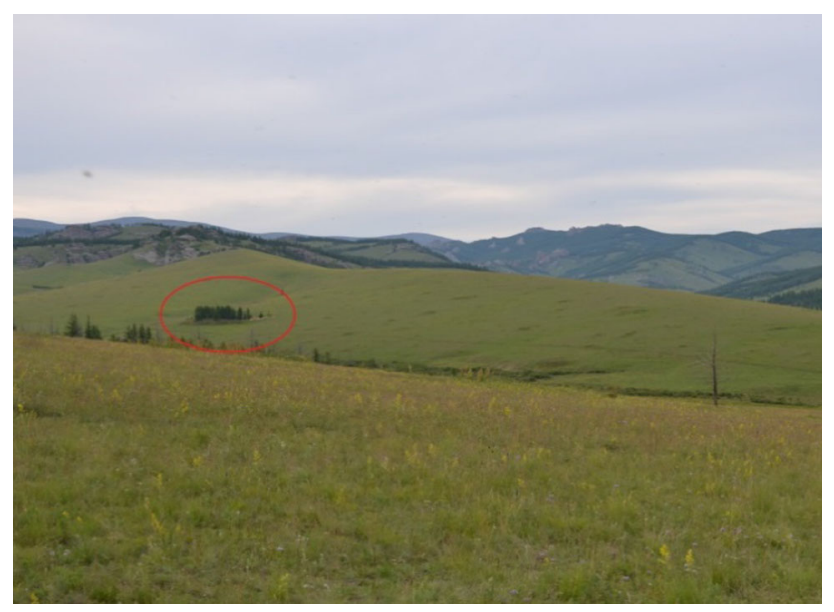

Fig. 11 Dumps with vegetation of Larix sibirica in the landscape context-Dzun Bayan (in a red circle)

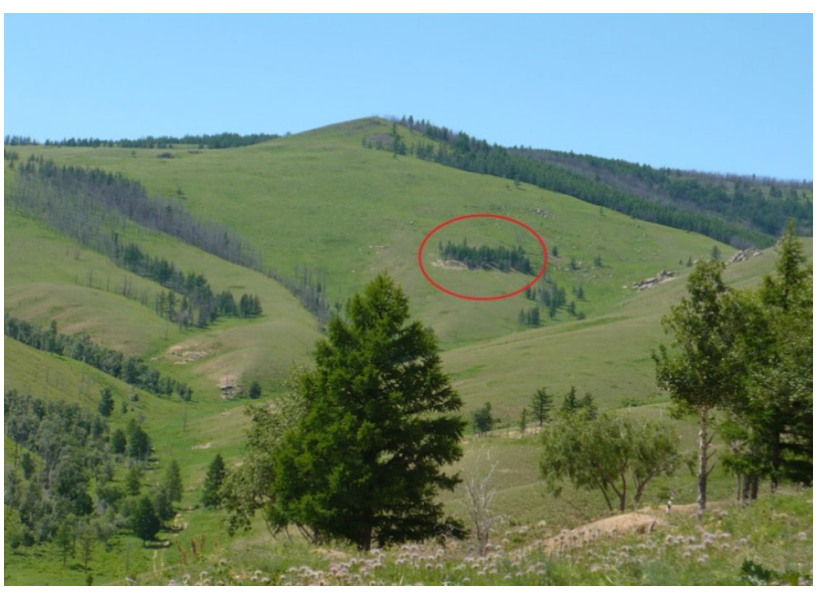

Fig. 12 Dumps with vegetation of Larix sibirica in the landscape context-Goricho (in a red circle)

through up to bedrock using a blade. It can be compared to the activity of the glaciers and the formation of glacial valleys with moraine at their end.

\section{Active condensation area of canavas and dumps}

The active condensation area (ACA; in Nikolayev et al. 1996 "working layer") of a model canava, whose lateral mounds are $50 \mathrm{~m}$ long (ordinary canavas length), equals to $\sim 161.24 \mathrm{~m}^{2}$; the end mound ACA equals to $21.24 \mathrm{~m}^{2}$ (Fig. 8, $X=\max 5 \mathrm{~m}, Y=\max 1.5 \mathrm{~m}, Z=\max 3.28 \mathrm{~m}$ ), length of lateral mounds-2 $2 \times 70 \mathrm{~m}^{2} ; 123$-m-long canava (the longest measured canava) has ACA of $365.80 \mathrm{~m}^{2}$.

The model dump of standard size, as shown in Fig. 5 $(X=\max .8 \mathrm{~m}, Y=\max .2 \mathrm{~m}, Z=\max 15 \mathrm{~m}$ ), has ACA of $109.55 \mathrm{~m}^{2}$. Having transformed the heterogeneous dump shape into a block without base $(15 \times 2 \times 2.6 \mathrm{~m})$, the increase by $1 \mathrm{~m}$ on axes $x, y$ and increased ACA equals to rounded $66 \mathrm{~m}^{2}$.

\section{Characteristics of soil-forming material on localities after mining}

Dumps in Goricho areas and Dzun Bayan are of soilforming substrate characteristics. There are found psephitic fraction with boulders, highly enriched with fragments of quartz and potassium feldspar, which has been created by excavating the pegmatite vein.

Canavas situation is similar to dumps both at Goricho and Dzun Bayan. Regarding the grain size fractions, only the composition of the crushed rock is different. Canavas cross the slope and expose more rock types along its entire length. In Goricho, it is a coarse-grained granite and 
pegmatite. Along most of the length of the canavas, the granite dominates in the bedrock. Pegmatite is recognized only marginally, up to a maximum of $1 \%$ of its length. At mined areas, there is no accumulation of silt particles likely removed by wind erosion from the surrounding slopes of the steppe character. Accumulation and decomposition of dead organic matter is insignificant due to the low quantities of phyto-mass produced by herb layer (Figs. 2, 6).

\section{Quantitative dendrology characteristics of measuring trees}

Canavas in Goricho (Figs. 2, 6), irrespective of their position and exposure, are colonized by Siberian larch and poplar, rarely by birch and willow. They are located exclusively on the steppes. Canavas of length up to $120 \mathrm{~m}$ are overgrown with up to 11 individuals of live Siberian larch. Apart from live specimens, dead individuals are also present in canavas that are approximately of the same size as healthy trees. There were found 18 individuals of live trees per one canavas at maximum. There are on average three trees per one canava. The heights of trees are on the average $7.6 \mathrm{~m}$. Canavas are covered with trees from the highest altitudes up to mound at their end. However, the most trees grow in the bottom parts of canavas (at their end-across contour lines). Herb layer of canavas and small-scale mines do not exceed $5 \%$ of its coverage.

Dumps at Goricho and Dzun Bayan are colonized by Siberian larch and poplar. Features and coverage of larch vegetation varies depending on the size of the dump. At dumps, where coverage does not exceed $30 \mathrm{~m}^{2}$, there are isolated groups of trees of 5-10 individuals. If the dump exceeds $70 \mathrm{~m}^{2}$ area, we can speak about continuous growth of larch with coverage about $70-90 \%$. It is a better result comparing to canavas where trees do not make continuous tree layer coverage.

\section{Qualitative dendrometric characteristics of measuring trees}

Larix sibirica at a canava (Table 1) shows the average physiological vitality degree of 2 (increasing value indicates worsening conditions), i.e. a slight deviation from the normal state with the prospect of a return to normality. The median for this parameter is the degree of 3 ; i.e. it already shows significant deviations from the normal state. However, existence of the tree is still not threatened. The total biomechanical vitality of $L$. sibirica is an average and median to the degree 2 , which expresses slight damage and the prospect of long-term existence. In case the arbory value is on average and median degree 3 , the tree shows significant deviations from normal habitat, e.g. insect damage, although their health is less than half the size achievable at the site; it is from medium- to long-term perspective. Dendrological research potential areas are on average degree 2 ; i.e. the composed vegetation element is either a partial or currently possible decomposition. Populus on canvas shows better characteristics in the median of the physiological vitality. Total biomechanical vitality and arbory value are the same as in case of Larix. Diameter of the dendrological potential research area is on average, median at degree 1 , and it shows improvement over Larix on average within 1 degree.

Dead trees were found only in canavas. On dumps there was zero tree mortality. Dead trees belonged only to species $L$. sibirica and $P$. tremula. Overall, 101 dead trees were counted on canavas; the living-to-dead trees ratio (Table 2) is 1.4:1, in favour of living trees. Larix sibirica mortality was higher than that of Populous.

Larix on dumps shows the average parameters value as well as the median of physiological vitality degree 1; i.e. there are no or only minimal deviations from the optimum; therefore, this state can be long time preserved. Equally, the total value of biomechanical vitality is on the degree 1 , i.e. no damage, just a small deviation from the normal state. The mean and median values of the "arbory value" are on the 2 degree; i.e. the state of certain deviations from the normal state is classified as a long term. Dendrological potential research areas are on the degree 1; i.e. composed vegetation element shows a long-term stability.

Populus on dump at the parameters of physiological vitality is at median and average on degree 3 , i.e. strong deviations from a normal state, and the improvement is not probable. The value of total biomechanical vitality is at stage 3 , at median and average. The arbory value in median and average on degree 4 , i.e. the tree vitality is significantly reduced; its short existence is assumed. Dendrological potential research areas are on degree 2, in both median and average.

The site analysis is required in order to confirm hypothesis of condensing humidity as the major factor of larch expansion outside the continuous forest through the canavas and dumps, and their suitability as starting models for rehabilitation work. Discussing dendrological properties of canavas and dumps can help to specify whether a dump or canava is better as an initial model for technical adjustments to reforestation. It has to be noted that the canavas and dumps are discussed from the viewpoint of air humidity condensation, and not as systems to capture and accumulate precipitation or groundwater.

The question is why larch colonizes canavas and dumps, i.e. severely anthropogenically degraded habitat on the steppe; why the steppe itself is not colonized as for its 


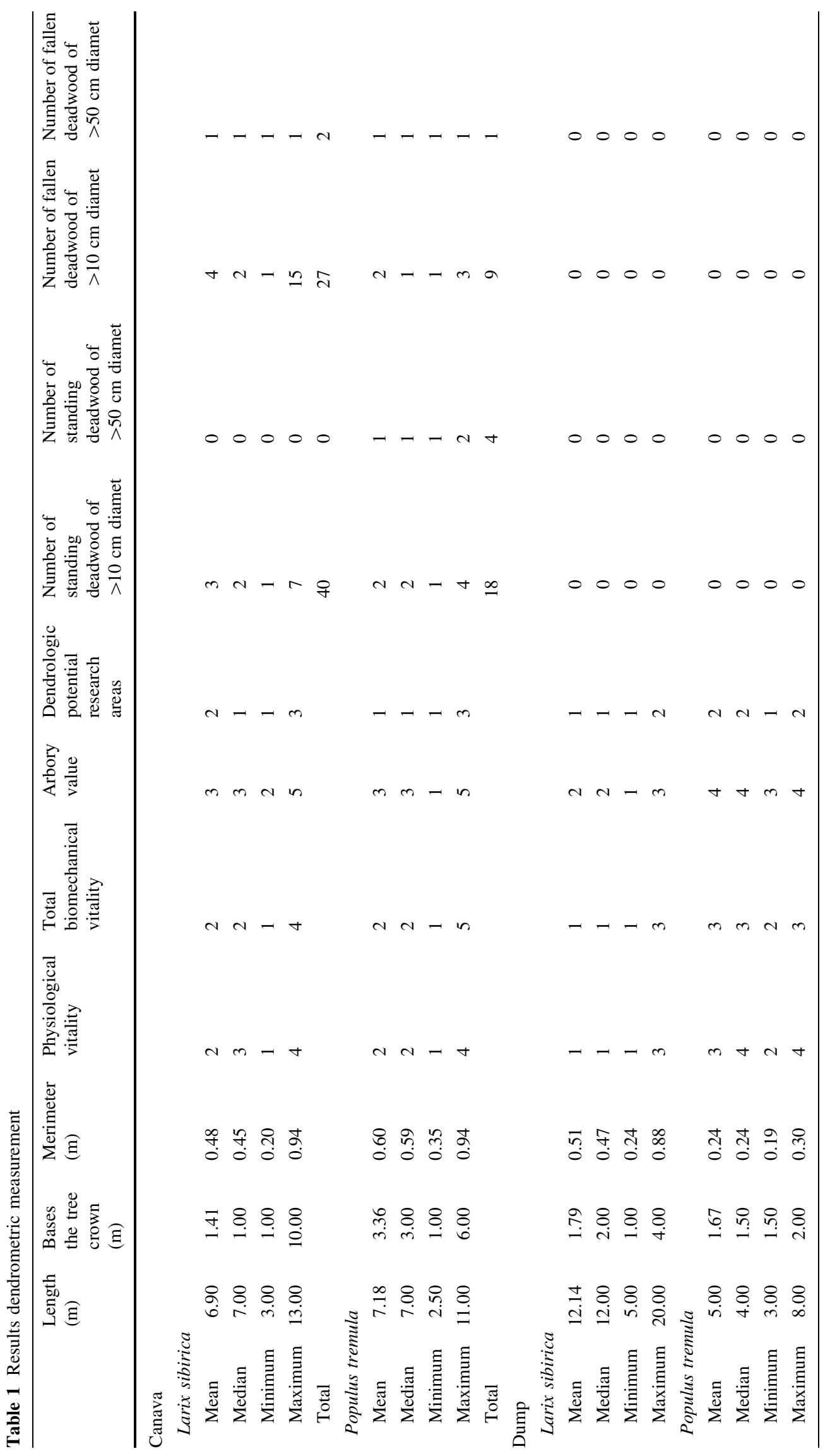


Table 2 Live-to-dead trees ratio

\begin{tabular}{ll}
\hline Canava & Live-death \\
\hline In total & $1.4: 1$ \\
Populus tremula & $1.6: 1$ \\
Larix sibirica & $1.2: 1$ \\
\hline
\end{tabular}

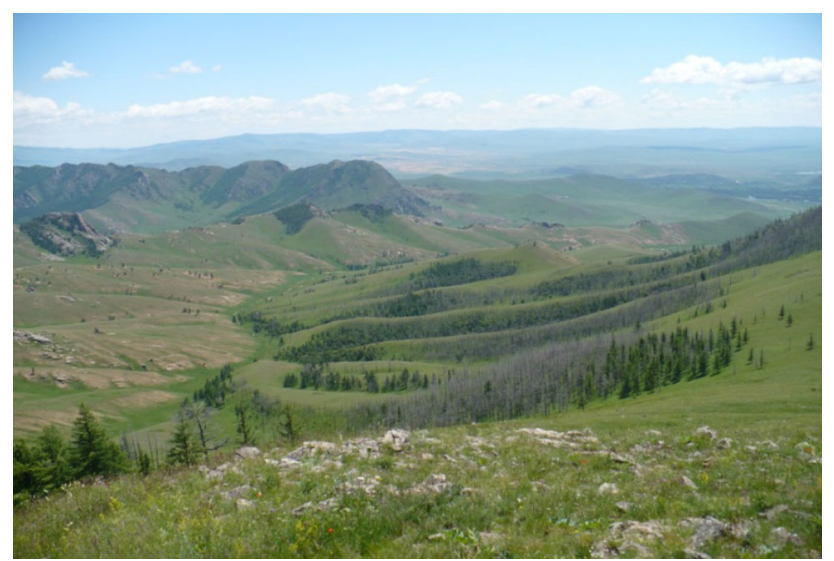

Fig. 13 Valley with stands of Larix sibirica draining slopes of Goricho massive

better soil conditions. Soils on the steppes locations Dzun Bayan and Goricho have developed B (metamorphic) horizon, which is $0.34 \mathrm{~m}$ wide. They are enriched with organic matter and have significantly improved retention capacity due to higher content of aleuritic fraction and humus. In contrast, soils in the mined areas virtually do not exist. They were removed, and they did not recover. Their soil-forming substrate corresponds to the classification of pedological horizon "C" (bedrock).

The explanation can consist in favourable humidity conditions of mined areas. Noy-Meir (1973) and Webb et al. (1983) suggested that the soil humidity is a crucial factor affecting plant productivity in semiarid areas. Even the incidence of strips of larch stands (length up to $100 \mathrm{~m}$ ) filling the small valley on the steppes far from continuous stands of larch (Fig. 13) suggests this fact. Groundwater concentrates in valleys and the environment, where water is available for vegetation for a longer time. In higher altitude valleys, water is collected both from precipitation and groundwater of permafrost melting origin; after that, water is further drained to valleys in lower altitudes (Fig. 13). There dominate birch trees (Betula platyphylla) and its related species; in addition, occasional presence of willows (e.g. Salix miyabeana) is found. Similarly, Dulamsuren et al. (2009) and Tsogtbaatar (2004) state the places with best moisture conditions are covered with the forest. This fact creates a typical forest-steppe landscape fragmented by moisture conditions of the habitat to forest (well supplied with water) and steppe communities (worse supplied with water).

Mined areas are well supplied with water in two ways. At standard mining, in some cases the groundwater level becomes exposed and water rises to the surface (Sutherland 2010). This results in stable and permanent wetting of soilforming substrate. Canavas and dumps get moisture in a different way. Canavas and dumps are often not deep enough to expose the groundwater level. Thus, we assume that the major source of water for the plants there results from condensing humidity.

Dumps with their structure and shape resemble the socalled Zibold condenser (Fig. 14), a replica of the alleged ancient condenser of moisture, which was to supply clean drinking water to the city of Feodosia in Crimea. Zibold condenser is of a cone shape whose upper part is cut off; on the top, there is a funnel formed by layered stones of various shapes. We assume principle of Zibold condenser is identical to the process that occurs in canavas and dumps. During the night, when there is a drop in air temperature, the warm air is forced out of the centre of the condenser. The stones are cooled, which is accelerated by the wind. At a certain time, at night and in the morning, moist condenses on cold stones by surrounding warmer moist air (Nikolayev et al. 1996).

Beysens (1995) states amount of condensed water is dependent mainly on the difference of temperatures between a condenser and its surrounding, degree of air saturation with moisture and properties of condenser surface. Marin (2010) reports there are high temperature differences between day and night in Mongolia. The temperature difference between day and night can reach even $24{ }^{\circ} \mathrm{C}$ (Weatherbase 2015). It can cause sufficient cooling of the substrate enabling condensation. Nikolayev et al. (1996) states condenser with active surface of $50 \mathrm{~m}^{2}$ can produce about $40 \mathrm{~kg}$ of water per day and with surface of $100 \mathrm{~m}^{2}$ about $70 \mathrm{~kg}$ of water. The ratio of active surface to the condensed water is not exponential. Area of $2000 \mathrm{~m}^{2}$ is producing about $1000 \mathrm{~kg}$ of water per day (Nikolayev et al. 1996). The area between 50 and $100 \mathrm{~m}^{2}$ corresponds to sites (dumps) with ideal succession. Canavas, dumps and quarries can supply moisture for larches even in cases of no vertical precipitation. Steppes are not supplied with such condensed water. Li (2002) presents better conditions of water condensation on the ground surface: in particular, on mulch with particle size less than $2 \mathrm{~mm}$ (corresponding to steppe) than on mulch with particle size $0.05-20 \mathrm{~mm}$ (corresponding to canavas and dumps). Nevertheless, we expect that these substrates, resembling those that occur naturally in the steppes of surveyed sites in Mongolia, are worse supplied with moisture than dumps and canavas. It is due to insufficient cooling of relatively flat ground during the night, which would ensure air condensation in the 
Fig. 14 Cross section of F.I. Zibold condenser (initial state) (Nikolayev et al. 1996)

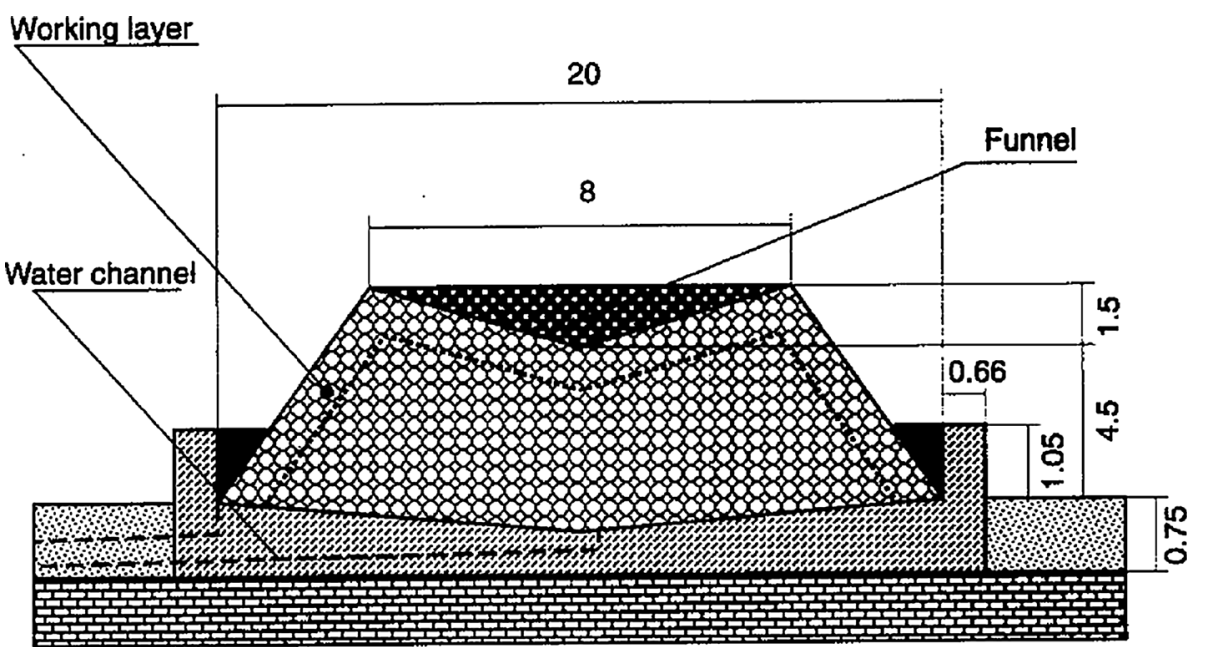

Beach pebbles

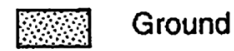

廖茲 Concrete bowl
Natural limestone base morning. Conversely, shape of canavas and dumps allows achievement of the necessary cooling.

Specific habitat conditions of quarries, canavas and heaps allow growth of only a few resistant tree species (Andersson 2005; Falaleev 1985). Although moisture conditions of these habitats are premium if compared to the steppes, the exposure of extreme weather conditions make possible to grow only $L$. sibirica, P. tremula, Limited $B$. platyphylla. Larix numerically predominates (Table 1); most of these trees tolerate extreme environmental conditions and seemingly unfavourable habitat characteristics are used in their favour.

Open surfaces of canavas are favourable for larch for the growing space. Succession of the canavas and the smallerscale mine work progress very slowly. Herb layer in comparison with the surrounding slopes is very poor in terms of both biodiversity and created phyto-mass; e.g. 34 years after the mines closure (personal observation), the recovery of the original herb layer starts even from $10 \%$. Larch requires enough light for the growth; therefore, minimum herb layer can offer friendly and relevant environment for its further development (Falaleev 1985). Larch also tolerates these unfavourable soil conditions. Wide valence of a larch enables to root in highly skeletal soils with minimal admixture of organic matter and nutrients. It can grow in sand, loamy-sand and peat-bog soils (Falaleev 1985; Abaimov et al. 1997). Larch tolerates temperature conditions of newly colonized areas that may negatively affect succession especially in winter and may slow it down. James (2011) states that the growth dynamics of $L$. sibirica and Picea obovate show strong negative correlation as it responds to changing month temperatures. It can be assumed that during sufficiency of moisture, the tree will be able to withstand extreme climatic effects due to influence of its exposition in the framework of smaller cluster of individuals within open area. The sensitivity to temperature of a tree has been doubted by Wilmking et al. 2004; D'Arrigo et al. 2008. There are even authors who support correlation of a tree and temperature (Barber et al. 2000; Sturm et al. 2001); e.g. Barber et al. (2000) states positive correlation between growth of the tree Alaskan white spruce and temperature. Anyway, in this case, the temperature is a factor causing moisture stress. The case described by Sturm et al. (2001) suggests a loosening of extreme climatic conditions of paraclimax of Antarctica, which led to strengthening of the growth dynamics and expansion of shrubs by about $320 \mathrm{~km}^{2}$ over the last 50 years. In these cases, there was no direct affect on a tree but the improvement of environment enabled the expansion and prosperity of the species.

Canavas and dumps create suitable conditions for the larch growth. Yet the dump seems more appropriate as initial shape for the character design and final landscaping. Mapping showed the ratio of live to dead trees at canavas in total 1.4:1, larch 1.2:1 and poplar 1.6:1 (Table 2). Dumps show no tree mortality. Thus, larch also survives on the dumps very well and shows great vitality values of measured parameters (Table 1). Average and median of values of physiological vitality, total biomechanical vitality and total dendrological potential are at degree 1, "arbory value" at degree 2 . The growths have high prospects of long-term survival and are of very good health. The highest 
values of the measured parameters of vitality larch at dumps are at maximum at degrees 3. Dumps were not friendly to poplar; it showed the worst readings from all stations. The average values of physiological vitality, total biomechanical vitality is at degree 3 , "arbory value" value at degree 4 and the total dendrological potential is 2 . Therefore, poplars are in a poor state of health and their long-term survival is not realistic.

Larches at canavas were found in a very poor condition, physiological vitality, total biomechanical vitality were highly at degree 4 ( 5 being the worst), "arbory value" at degree 5 , and the total dendrological potential was at degree 3 , without the potential long-term survival. In canavas larch keeps on to the central until slightly above the average values of the measured parameters $(2,3)$. It shows the average health status with the prospect of long-term survival. Poplar tolerates canavas conditions a little better than larch, exhibiting long-term prospects for survival.

We assume that the better larch growth on dumps compared to canavas is caused by the dump shape; specific dump shape can create more favourable moisture conditions than canavas despite the overall lower dump ACA. Substantial water quantity formed on the canavas ACA is scattered within considerably long lateral mounds of minimum $50 \mathrm{~m}$; this fact may result in significant losses of condensed water. The crucial losses can be caused by solar radiation: lateral canava mounds are long elongated bodies of a roughly triangular cross section; the solar radiation intensifies during the day, the mounds can warm faster, therefore, the evaporation is more intense compared to dumps (Nikolayev et al. 1996). However, there is another significant factor as well: since the canavas are warmed faster, the condensation process takes shorter than dump condensation period; dumps due to their pile-shape are able to keep cold longer. This fact shows that ACA is not the essential factor of water production; however, the area shape is of highly prominent importance.

In case of dumps, there is a challenge for reforestation work in Mongolia with the intention to stop the expansion of the Gobi Desert to the north. The solution can consist in landscaping, similar to dumps. Their length, depth and height will be adapted to the natural conditions of the site (slope, exposure, bedrock): 10- to 20-m-long, 1- to 2-mhigh and 8-m-wide dumps work well in nature. They are covered with groups of healthy matured larches with tree canopy coverage (Figs. 11, 12). Debris fields in Goricho (Fig. 15) are examples of another site, which is characteristically similar to dumps; they are overgrown with solitary $L$. sibirica in less extend; this is a place outside the continuous stand of larch surrounded by steppe. Commonalties with dumps are highly unfavourable soil conditions for growth because the soil is created only by rock fragments; in this case, stones range from 0.3 to $0.5 \mathrm{~m}$ in diameter with

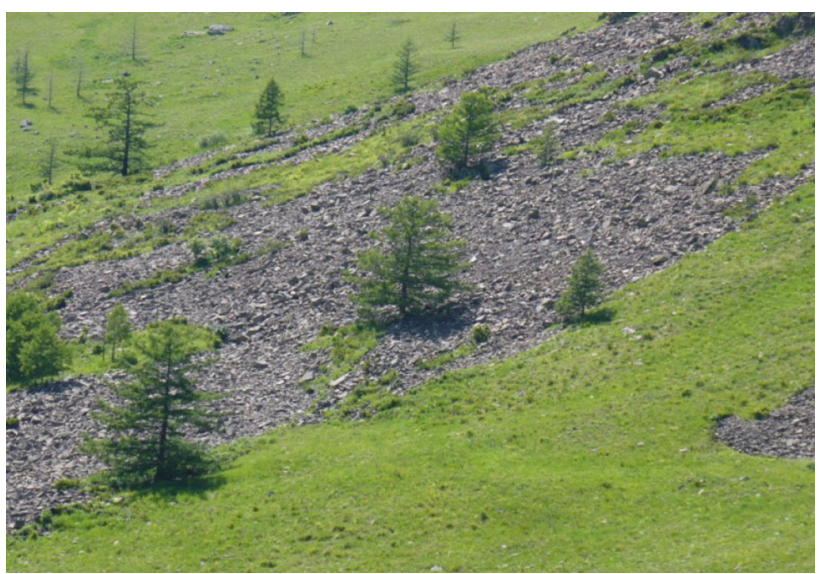

Fig. 15 Stands of larch in debris, locality Goricho

no soil organic matter present. The moisture is provided through water condensation on the rocks.

Water box works similarly (Coxworth 2010; Read 2015). It is a condensing bowl with a diameter of $0.5 \mathrm{~m}$ where water supplies young seedlings. This device is only suitable as a temporary solution for smaller trees. It does not solve the situation of grown trees. After a water box removal, water deficit may occur and the tree might suffer from subsequent drying. Moreover, there is a high risk of waste production if proper water box removal from seedling fails. Dumps are waste free and require only work of a limited number of workers and construction equipment.

The disadvantage of dumps may lack the herb layer, which belongs naturally to the ecosystem. This fact is not so significant for steppe slopes affected by aridization; those have already been covered with a low coverage of herb layer, which should be a primary objective of the reclamation work activities.

\section{Conclusion}

Remains as well as consequences from the period of the former Soviet Union mining activities in Mongolia as well as further reclamation have great potential for the following research. The existing research suggests and foresees there is a very promising direction for the development of reclamation work methodology dealing with problems how to mitigate or stop the expansion of the Gobi Desert in Mongolia to the north. Despite the slow progression of succession, where herbs do not participate, there is a noticeable positive effect on $L$. sibirica populations, which is extended to areas of arid steppes where it would not be normally present. The most vital stands were recorded in the dumps with a length of $10-20 \mathrm{~m}$ and height of about $2 \mathrm{~m}$. Larch vegetation, though already weaker, was also noted in canavas. 
Canavas with length of up to $120 \mathrm{~m}$ were colonized mainly by larch. Trees thrive on these sites mainly due to condensation of air moisture, which is enabled due to the specific shape of the both canavas and dumps. Thus, it is possible to reach sufficient cooling compared to surrounding steppe, which allows the condensation of warmer air on a cold surface of the canavas and dumps in the early hours. Trees, particularly in the early stages of growth, are subsidized by sufficient amount of water, which is higher than on the steppe. Detailed comparison of both qualitative and quantitative $L$. sibirica parameters demonstrated that dumps are able to supply trees with water better than canavas; this fact results from the dump design: there are more favourable factors such as condensation duration and gradual evaporation.

Acknowledgments This study was supported by projects CZ.1.07/ 2.2.00/28.0306 (innovation of teaching at MENDELU with an emphasis on sustainable development of the country in the context of EU priorities), TA02020867 (use of the new organic mineral stimulators and natural organic materials for revitalization of the forest ecosystems influenced by biotic and abiotic impacts) and QJ1320040 (revitalization of the ecosystem units with the use of ecological principles on the sites with strong anthropic influence in the past and extreme sites)

\section{References}

Abaimov AP, Prokushkin SG, Zyryanova OA, Kaverzina LN (1997) Peculiarities of forming and functioning larch forests on frozen soils. Lesovedenie 5:13-23

Andersson F (2005) Coniferous forests. Elsevier, Amsterdam

Anenkhonov OA, Korolyuk AY, Sandanov DV, Liu H, Zverev AA, Guo D (2015) Soil-moisture conditions indicated by field-layer plants help identify vulnerable forests in the forest-steppe of semi-arid Southern Siberia. Ecol Indic 57:196-207

Antipin VS, Filippova B, Gerel O, Lyzin AV (1976) Geologic framework and origin of zonal hypabyssal intrusions. In: Geology and Geophysics, pp 44-55

Barber VA, Juday GP, Finney BP (2000) Reduced growth of Alaskan white spruce in the twentieth century from temperature-induced drought stress. Nature 405(6787):668-673

Beysens D (1995) The formation of dew. Atmos Res 93:215-237

Dashkhuu D, Kim JP, Chun JA, Lee W-S (2015) Long-term trends in daily temperature extremes over Mongolia. Weather Clim Extremes 8:26-33

D'Arrigo R, Wilson R, Liepert B, Cherubini P (2008) On the divergence problem in northern forests: a review of the tree-ring evidence and possible causes. Global Planet Change 60(3-4):289-305

Dulamsuren Ch, Hauck M, Bader M, Osokhjargal D, Oyungerel S, Nyambayar S, Runge M, Leuschner C (2009) Water relations and photosynthetic performance in Larix sibirica growing in the forest-steppe ecotone of northern Mongolia. Tree Physiol 29(1):99-110

Falaleev EN (1985) Siberian forests. KGU Publ, Krasnoyarsk, p 134 (translated, original in Russian language)
Hu Q, Pan F, Pan X, Zhang, D, Li Q, Pan Z, Wei Y (2015) Spatial analysis of climate change in Inner Mongolia during 1961-2012, China. Appl Geogr 60:254-260

James MT (2011) Temperature sensitivity and recruitment dynamics of Siberian larch (Larix sibirica) and Siberian spruce (Picea obovata) in northern Mongolia's boreal forest. For Ecol Manage 262(4):629-636

Khishigjargal M, Dulamsuren $\mathrm{Ch}$, Leuschner $\mathrm{HH}$, Leuschner $\mathrm{Ch}$, Hauck M (2014) Climate effects on inter- and intra-annual larch stemwood anomalies in the Mongolian forest-steppe. Acta Oecol $55: 113-121$

Kynicky J, Brtnicky M, Vavricek D, Uondon M (2009) Permafrost and climatic change in Mongolia. In: Sustainable development and bioclimate: reviewed conference proceedings, pp 34-35

Kynický J, Jaroš O (2005) Pegmatity masívu Gorkhi: Topazové miaroly. In: Hlavní výsledky průzkumu území Mongolska v projektu Mongolsko 2000-2005: shrnutí, hodnocení a interpretace. 14 December, Brno, Czech Republic

Kynický J, Jaroš O, Slavik M, Samec P, Novák J, Texl V, Skoták V, Kisza L, Schejbalová H, Pubal J, Kynická A, Hönig S (2005) Výsledky průzkumu dutinových pegmatitů granitického masívu Dzunbayn. In: Hlavní výsledky průzkumu území Mongolska v projektu Mongolsko 2000-2005: shrnutí, hodnocení a interpretace. 14 December, Brno, Czech Republic

Li X-Y (2002) Effects of gravel and sand mulches on dew deposition in the semiarid region of China. J Hydrol 260(1-4):151-160

Li H, Yang X (2014) Temperate dryland vegetation changes under a warming climate and strong human intervention - With a particular reference to the district Xilin Gol, Inner Mongolia, China. Catena 119:9-20

Lioubimtseva E, Cole R, Adams JM, Kapustin G (2005) Impacts of climate and land-cover changes in arid lands of Central Asia. J Arid Environ 62:285-308

Marin A (2010) Riders under storms: contributions of nomadic herders' observations to analysing climate change in Mongolia. Glob Environ Change 20(1):162-176

Mühlenberg M, Appelfelder J, Hoffmann H, Ayush E, Wilson KJ (2012) Structure of the montane taiga forests of West Khentii, Northern Mongolia. J For Sci 58(2):45-56

Nikolayev VS, Beysens D, Gioda A, Milimou I, Katiushin E, Morel J-P (1996) Water recovery from dew. J Hydrol 182(1-4):19-35

Noy-Meir I (1973) Desert ecosystems: environment and producers. Annu Rev Ecol Syst 4:25-51

Šimek P (2014) Vyhodnocení dendrologického potenciálu objektu. Summary of project: DF11P01OVV019-Metody a nástroje krajinárské architektury pro rozvoj území (2011-2015)

Sturm M, Racine C, Tape K (2001) Climate change: increasing shrub abundance in the Arctic. Nature 411(6837):546-547

Sutherland K (2010) Mining and metallurgy: the role of filters in mining and quarrying. Filtration 47(1):24-27

Tsogtbaatar J (2004) Deforestation and reforestation needs in Mongolia. For Ecol Manage 201(1):57-63

Wilmking M, Juday GP, Barber VA, Zald HSJ (2004) Recent climate warming forces contrasting growth responses of white spruce at treeline in Alaska through temperature thresholds. Glob Change Biol 10(10):1724-1736

Webb WL, Lauenroth WK, Szarek SR, Kinerson RS (1983) Primary production and abiotic controls in forests, grasslands, and desert ecosystems of the United States. Ecology 64(1):134-151

Ykhanbaiet H (2010) Mongolia forestry outlook study. Asia-pacific forestry sector outlook study II: working paper no. APFSOS II/ WP/2009/21

Zbíral J (1996) Analýza půd II—jednotné pracovní postupy. ÚKZÚZ, Brno 


\section{Web sources}

Coxworth B (2010) Groasis Waterboxx lets trees grow up in unfriendly places. Gizmag. http://www.gizmag.com/groasiswaterboxx-helps-trees-get-started/16991/

Read PK (2015) Innovation for Sustainability: The Groasis Waterboxx fights desertification, one tree at a time. Food Tank. http:// foodtank.com/news/2014/03/the-groasis-waterboxx-fights-desertification-one-tree-at-a-time

Weatherbase (2015) Ulaanbaatar, Mongolia. Weather Almanac. CantyMedia. http://www.weatherbase.com/weather/weather hourly.php3?s=29244\&cityname=Ulaanbaatar-Ulaanbaatar-Mon golia\&date $=2015-05-12 \&$ units $=$ metric 